\title{
Corporate Governance and Bidder Abnormal Returns in M\&A
}

\author{
Yao CHENG \\ Business School, Beijing Language and Culture University, Beijing, China \\ chengyaoblcu@163.com
}

\begin{abstract}
China's domestic mergers and acquisitions during 2010-2016. This paper examines a range of corporate governance measures while controlling for bidder and deal characteristics. Our long-term regression analyses show that the positive impact of executive ownership remains. Independent directors record a negative effect on abnormal returns.)
\end{abstract}

\section{Introduction}

Mergers and acquisitions (M\&As) is one of the most thoroughly and extensively researched topics in finance due to its profound implications for wealth on the part of all parties involved. Research evidence suggests that target firm shareholders earn positive and significant returns around announcement date while bidder firm shareholders obtain at best negligible positive, zero or negative returns (Sudarsanam and Mahate, 2013). Fuller et al. (2002) associate positive returns to the resulting combination with the transfer of wealth from bidders to targets. There is, however, no evidence to suggest that M\&As create value for shareholders in the long run (Sudarsanam and Mahate, 2006).

It is in this context that the present study seeks to examine the impact of corporate governance mechanisms on bidder abnormal returns. This study examines shareholders wealth effects and the role of corporate governance in the M\&A decisions in an emerging economy: China. China is a special case for an investigation of this relation due to its increasingly active M\&A activities and unique market characteristics (Kakabadse et al., 2010).

Unprecedented economic growth and the promulgation of the corporate law in the early 1990s have resulted in rapid development of financial markets and phenomenal growth of M\&A activities. A report by Baird and Company (2012) shows that from the year 2001 to 2009 , China's M\&A increased at the speed of $20.5 \%$ compounded annual growth rate. The report also shows that in 2010 domestic M\&A deals rose by $12 \%$ over 2009 , reflecting healthy economic fundamentals and a slightly larger risk appetite among bidders. Despite the rapid growth and the importance of M\&A activities in the real economy, there has been a dearth in literature on the M\&A market in China.

\section{Literature Review and Hypotheses Development}

\subsection{Wealth Effects around M\&A Announcement Date}

Most research on M\&A in China is limited and inconclusive or is based on small sample size. $\mathrm{Li}$ and Chen (2002) find positive returns for bidder firms, which they attribute to state intervention in the process and the private firm liquidity discount. Similarly, Zhang and Wang (2006) report positive earnings for bidder firms and attribute that to insider trading and the fact that M\&A transactions were still a new phenomenon in China.

Again, Song et al. (2008) record positive and significant returns around announcement date from a study of 23 acquisitions announced between 1998 and 2007. Chi et al. (2011) examine the performance and characteristics of bidding firms on 1148 Chinese acquisitions from 1998 to 2003 , and find positive abnormal returns of $0.27 \%$ over a three-day event window. Chi et al. (2011) research also highlights that the political advantages of bidding firms have a significantly positive impact on the bidders' performance, while the economic advantages do not. By contrast, Zhang (2003) find negative returns and conclude that hubris and agency hypotheses explain why bidding companies lose value. Given that the Chinese government is heavily involved in the M\&A process as both owner and regulator and the private firm liquidity discount, it is hypothesised, in its null form, that:

H1: Bidder abnormal return around $M \& A$ announcement date are positive and significant. 


\subsection{Corporate Governance and Bidder Returns}

A number of studies have tested corporate governance mechanisms within the M\&A context. Previous research highlights the importance of the ownership structure in determining bidder abnormal returns around M\&A announcement (Shim and Okamuro, 2011). Specifically, Megginson and Netter (2007) note that state ownership has an impact on firm performance especially in emerging countries. The association between state ownership and investment decisions is generally not sufficiently explored and particularly in China. There are studies that criticise state ownership of firms because of political intervention and the need to help achieve government objectives instead of profitability (Sun and Tong, 2003; Wei et al., 2005).

However, Chen et al. (2009) findings support Stiglitz (1999) results that market- oriented state shareholders may be the most suitable controlling owners of firms in countries with weak institutional environments. Additionally, Chi et al. (2011) suggest that state ownership is not necessarily associated with negative bidder abnormal returns. Given that state ownership has been associated with neglecting profitability objectives in favour of social objectives, it is hypothesised stated in its null form, that:

H2.1: There is a significant and negative relationship between state ownership and bidder returns around $M \& A$ announcement.

Agency theorists prefer a board dominated by independent non-executive directors. They argue that boards dominated by non-independent directors have less incentive to monitor management (Mallin, 2010). Prior research highlight that the presence of independent directors on the board of directors plays an important role in monitoring managers' decision- making process (Fama and Jensen, 1983).

In support, Byrd and Hickman (1992) find that tender offer bidders are best served when outsider representation is close to $60 \%$ of the board. Additionally, Kroll et al. (2008) and Masulis et al. (2007) find similar results. There are no direct studies on China. Existing evidence from corporate governance and firm performance is mixed (Yang et al., 2011). Given the evidence from Qui and Yao (2009) in the Chinese context, it seems reasonable in spite of the mixed results on the relationship between independent directors and bidder returns to hypothesise, stated in its null form, that:

H2.2: There is a significant and positive relationship between board independence and bidder announcement returns.

\subsection{Control Variables}

Our study controls for a number of bidder specific and deal specific characteristics which are expected to influence the bidder returns.

Bidder characteristics

This study controls for firm specific characteristics including Tobin's q, leverage administration, transactions and size, of which are measured at the end of the year prior to the announcement date.

Deal characteristics

The study also controls for deal characteristics including method of payment, listing status of the target firm, value of the transaction, diversifying or focusing acquisition and previous M\&A experience.

\section{Data and Methodology}

\subsection{Sample Selection}

Our study focuses on domestic M\&A deals between January 2010 and December 2016 by Chinese listed firms. The initial data set is obtained from the China Stock Market and Accounting Research (CSMAR) database. It comprises 26,763 deals.

The bidder is a Chinese firm with Class 'A' shares traded on the Shanghai or Shenzhen Stock Exchange, while the target firm can be a listed public firm or a private firm (Cosh et al., 2006). The status of the deal must be successful with the deal value disclosed. To avoid the results generated by very small transactions (Fuller et al., 2002), the amount paid for the target should be at least 1 million Chinese Yuan. M\&A involving firms in the financial industry are excluded, because they are subjected to special accounting and regulatory requirements. To ensure that the movement in the share price is due to the M\&A announcement and not to other confounding events, we controlled for confounding events by removing announcements with such events as share splits, dividend and earnings announcements, and executive changes within the event window from the sample. Our final sample comprises 1,921 M\&A transactions.

\subsection{Sample Characteristics}

Table 1 presents an overview of the final sample of M\&A deals.

Panel A shows the distribution of M\&A deals by the year of announcement. The general trend that has characterised the Chinese M\&A market over the last decade: increase in both the number of deals and the value of the transactions over time as indicated by rising average deal values. Cash payment dominates both the number of deals $(90.06 \%)$ and the total value of transactions (58.84\%). However, on average very large deals tend to be paid by stock or mixed payment methods. The average size of deals paid with equity was CNY1630 million and paid by a combination of methods was CNY1180 million. The average size of deals paid in cash are relatively small at CNY180 million. This is consistent with Boateng and Bi (2010) who note that bidder firms in China prefer to finance M\&As by cash because they have large cash holdings and Chinese firms still prefer to deal with business transactions in cash.

Panel B shows the distribution of M\&A deals by bidder industry. $96.77 \%$ of the announced M\&A deals are negotiated. This is consistent with findings from Tuan et al. (2007) where the bidding firm takes over the target firm by negotiating with the major shareholders. Negotiated equity transfer accounts for $63.35 \%$ of the deals while $33.42 \%$ are negotiated asset transfer. There are $60 \mathrm{debt}$ restructuring cases accounting for $3.12 \%$ and only 2 tender offer 
announcements accounting for $0.10 \%$. However in terms of deal value, tender offers are conducted in the largest scale recording an average deal value of CNY886 million, which is followed by asset transfer with CNY419 million.

\subsection{Methods}

We employ the bidder abnormal returns around the announcement date and post-M\&As as the dependent variables and corporate governance mechanisms as the key explanatory variables. We use bidder characteristics and deal characteristics as control variables.

Bidder abnormal returns post-M\&A

To calculate BHAR, firstly, the returns of the firms and benchmark returns (market returns) are compounded individually. Secondly, the difference between the returns of the bidding firms and the returns of the equally weighted market returns is calculated to derive the BHAR.BHAR is calculated for a 24-month postacquisition period, starting with one month after the announcement date.

Multivariate analysis

We also control for deal specific characteristics such as listing status of the target firm, diversifying acquisitions, method of payment, the deal value and repeat bidders. Specifically, public target is a dummy variable equal to 1 if the target is listed on the stock exchange or 0 otherwise. Diversifying acquisition is a dummy variable equal to 1 for diversifying acquisition or 0 otherwise.

Two methods of payment indicators are created for all cash-financed and all stock-financed deals. All cash equals to 1 when the M\&A transaction is fully financed with cash or 0 otherwise. All stock equals to 1 when the M\&A transaction is financed fully with stock or 0 otherwise. The deal value is measured as the $\log$ transformation of Chinese Yuan value of the M\&A deal. Repeat bidder is a dummy variable equal to 1 if the bidder is engages in more than one deal or 0 otherwise. To capture the effects of the ownership status of the target firm, the target variables are interacted with the method of payment variables to create the mutually exclusive and exhaustive deal categories.

To avoid the problems of multicollinearity, the dummy construction rule is applied and therefore only public target $\mathrm{x}$ all cash, private target $\mathrm{x}$ all stock and private target $\mathrm{x}$ all stock variables will be used in hypothesis testing.

\section{Empirical Results}

\subsection{Descriptive Statistics}

Table 2 presents the summary statistics of the corporate governance, bidder specific and deal specific characteristics variables. The results show some of the salient features of the Chinese board structure and composition.

On average, the total number of directors in a board range from 5 to 19 , the figures recommended by the Chinese Company Law guidelines. An average board size is 9.22 with a median of 9 . This reflects full compliance by the Chinese listed firms with the regulation and is consistent with prior studies (Huyghebaert and Wang, 2010).

The results also show the continued downward trend in CEO/Chairman duality with $13.1 \%$ of the firms whose CEOs still hold the dual positions. Currently the CSRC requires that the number of independent directors sitting on a board should be at least 0.33 of the total number of directors. On average, the results from the sample show that $80.1 \%$ of the sample firms are complying with the regulations. By comparison, companies have a board more than half of the board to comprise of independent directors in mature markets.

Table 2 further shows $90.2 \%$ of the bidding firms engage in diversifying deals. This suggests the possibility that firms attempt to achieve risk diversion through engaging inM\&A across different industries. On average, the value of the transaction is CNY 142 million with the values ranging between CNY 1.0 million (which is the selection criteria minimum cut-off value) and CNY 32,800 million and a median of CNY 38.9 million. These statistics imply that there are some very large deals. The values also vary considerably given a very high standard deviation of CNY 1,460 million. The results show that $73.0 \%$ of the M\&A transactions in the sample are by repeat bidders.

\subsection{Robustness Tests}

To ensure the reliability of our results, we conduct robustness checks for the multivariate analysis. For robustness tests, we calculated bidder abnormal returns in the short-term using the market adjusted returns model where abnormal returns is the difference between the stock returns and the market index returns. The results are are consistent with market model.

Finally, we conducted diagnostic tests on the regression results. High levels of correlations between independent variables can inflate standard errors resulting in lessefficient parameterestimates. To assess this possibility, we conducted two tests of multicollinearity. First, we checked correlations among independent variables using the correlation matrix. The correction between variables ranges between 0.01 and 0.64 , none exceeding the 0.80 threshold. Second, we conducted a variance-inflationfactor (VIF) test. The values rangebetween 1.04 and 3.51 and none of them is above the VIF threshold of 10 . The two tests thus provide evidence that multicollinearity is not a problem.

\section{Conclusion}

We study the shareholder wealth effects of China's domestic mergers and acquisitions in the period of 20062010. Specifically we examine how corporate governance influences both short-term and long-tern bidder abnormal returns. We demonstrate that market responses differ in ways which suggest a difference in how the market's assessment of share price from the perspectives of short run and long run. The results demonstrate that bidder firms experience wealth gains in the short run but lose value in the long run.

This paper shows that corporate governance structure 
play an important role in shareholders abnormal returns, there are several points that limit its scope.

First, measures of stock performance are sensitive to the methodology and choice of variables. Indeed, our review of the literature highlights that existing studies produce varying and sometimescontradictory outcomes.

Second, our study examines a sample from a particular country over a particular period and therefore its generalizability may be limited given the unique China's market environment.

Third, studies on this subject suffer from low explanatory power of theindependent variables as they are so many variables that influence decision making and this study is no exception.

We therefore recommend further research employing different approaches and more variables to shed new light on these issues. Future research could useother stock performance measures such as operating performance and calendar time approach. The attitude with respect to whether the deals are hostile or friendly is also an interesting topic worth investigation. Given the scarcity of literature on emerging markets, we recommend similar studies on other emerging markets for comparative purposes.

Finally, we recommend studies that consider both qualitative and quantitative methodologies when examining corporate attitude towards M\&As and its interaction with corporate governance.

\section{References}

1. Agrawal, A. and Jaffe, J. F. (2000). The post-merger performance puzzle. Advances in Mergers and Acquisitions, Vol. 1, p. 7-41.

2. Alexandridis, G., Petmezas, D. and Travlos, N. G. (2010). Gains from mergers and acquisitions around the world: New evidence. Financial Management, Vol. 39(4), p. 1671-1695, Winter.

3. Barber, B. M. and Lyon, J. D. (1997). Detecting longrun abnormal stock returns: The empirical power and specification of test statistics. Journal of Financial Economics, Vol. 43, p. 341-372.

4. Baird, R .W. and Company (2011). China M\&A Market: 2010 Review and Outlook for 2011 and Beyond. M\&A Market Analysis and Capital Markets Update, February 2011.

5. Bartholdy, J., Olson, D. and Peare, P. (2007). Conducting event studies on a small stock exchange, European Journal of Finance, Vol. 13(3), p. 227-252.

6. Bauguess, S. and Stegemoller, M. (2008). Protective Governance Choices and the Value of Acquisition Activity. Journal of Corporate Finance, Vol. 14(5), pp. 550-566.

7. Bhagat, S. and Bolton, B. (2009). Corporate Governance and Firm Performance: Recent Evidence. Available from (Accessed 26.06.2009).

8. Campa, J. M. and Hernando, I. (2004). Shareholder Value Creation in European M\&As. European Financial Management, Vol. 10(1), p. 47-81.

9. Chi, J., Sun, Q. and Young, M. (2011). Performance and characteristics of bidding firms in the Chinese stock markets. Emerging Markets Review, Vol. 12(2), p. $152-170$.

10. Deloitte. (2010). A long path to better corporate governance: 2010 China listed companies corporate governance survey. Deloitte Touché Tohmatsu CPA Ltd

11. Fama, E. F., Fisher, L., Jensen, M.C. and Roll, R. (1969). The adjustments of stock prices to new information. International Economic Review, Vol. 10 (1), p.1-21.

12. Gao, L. and Kling, G. (2008). Corporate governance and tunnelling: Empirical evidence from China. Pacific-Basin Finance Journal, Vol. 16, p. 591-605.

13. Jensen, M. C. and Ruback, R. S. (1983). The market for corporate control: The scientific evidence. Journal of Financial Economics, Vol. 11, p. 5-50.

14. Kato, T. and Long, C. (2006). Executives compensation, firm performance and corporate governance in China: Evidence from Firms listed in the Shanghai and Shenzhen stock exchanges. Economic Development and Cultural Change, Vol. 54(4), p. 945-983.

15. Li, L. and Naughton, T. (2007). Going Public with Good Governance: Evidence from China, Corporate Governance: An International Review, Vol.15(6), p.1190-1202.

16. Lieberman, M. B. and Asaba, S. (2006). Why do firms imitate each other? Academy of Management Review, Vol. 31(2), p.366-385.

17. Sudarsanam, P. S. (2003). Creating Value from Mergers and Acquisitions: The Challenges, An Integrated and International Perspective. FT Prentice Hall Harlow.

18. Wei, Z., Xie, F. and Zhang, S., (2005). Ownership structure and firm value in China's privatized firms: 1991-2001. Journal of Financial and Quantitative Analysis, Vol. 40 (1), p. 87-108.

19. Pangarkar, N. (2000). What drives merger behaviour of firms? Strategic Momentum vs. Bandwagons. International Journal of Organization Theory and Behaviour, Vol. 3(1\&2), p.37-72.

20. Rui O., Firth, M. and Fung, P. (2012). Corporate Governance and CEO Compensation in China, (September 2012).

21. Sudarsanam, P. S. (2003). Creating Value from Mergers and Acquisitions: The Challenges, An Integrated and International Perspective. FT Prentice Hall Harlow.

22. Tao, L. and Fie, X. (2014). The payment pattern of merger and acquisition: An empirical analysis from China's listed companies. Advanced Management Science (ICAMS), 2010 IEEE International Conference, Vol.3, no., p.575-581, 9-11 July 2010.

23. Uddin, M. and Boateng, A. (2009). An analysis of short run performance of cross-border mergers and acquisitions: evidence from the UK bidding firms. Review of Accounting and Finance, Vol. 8, p.431453.

Yang, J., Chi, J. and Young, M. (2011). A review of corporate governance in China. Asian-Pacific Economic Literature, Vol. 25(1), p. 15-28 
Table 1. Distribution of M\&A deals by year and bidder industry (Panel A: Distribution of M\&A deals by year of announcement)

\begin{tabular}{|c|c|c|c|}
\hline$\underline{\text { Year }}$ & $\begin{array}{l}\text { Mean deal value } \\
\text { (CNY millions) }\end{array}$ & $\underline{\text { Number of deals }}$ & Number of deals $(\%)$ \\
\hline 2007 & 68 & 41 & 2.13 \\
\hline 2008 & 105 & 105 & 5.47 \\
\hline 2009 & 119 & 139 & 7.24 \\
\hline 2010 & 87 & 184 & 9.58 \\
\hline 2011 & 268 & 165 & 8.59 \\
\hline 2012 & 309 & 163 & 8.49 \\
\hline 2013 & 338 & 328 & 17.07 \\
\hline 2014 & 331 & 285 & 14.84 \\
\hline 2015 & 322 & 257 & 13.38 \\
\hline 2016 & 398 & 254 & 13.22 \\
\hline All & 276 & 1,921 & 100.00 \\
\hline \multicolumn{4}{|c|}{ (Panel B: Distribution of M\&A deals by bidder firm industry) } \\
\hline Bidder industry & $\begin{array}{c}\text { Mean deal value } \\
\text { (CNY millions) }\end{array}$ & Number of deals & Number of deals $(\%)$ \\
\hline Agriculture & 70 & 46 & 2.39 \\
\hline Mining & 502 & 59 & 3.07 \\
\hline Manufacturing & 189 & 1,071 & 55.75 \\
\hline Utility & 459 & 104 & 5.41 \\
\hline Construction & 489 & 39 & 2.03 \\
\hline Transportation & 830 & 86 & 4.48 \\
\hline Information technology & 651 & 102 & 5.31 \\
\hline Retail and wholesale & 309 & 110 & 5.73 \\
\hline Real estate & 308 & 97 & 5.05 \\
\hline Service & 141 & 64 & 3.33 \\
\hline News and media & 55 & 7 & 0.36 \\
\hline Miscellaneous & 120 & 136 & 7.08 \\
\hline All & 276 & 1,921 & 100 \\
\hline
\end{tabular}


Table 2. Summary statistics

\begin{tabular}{|c|c|c|c|c|c|c|}
\hline \multirow{2}{*}{$\begin{array}{l}\text { Independent variable } \\
\text { Governance variables }\end{array}$} & \multirow[t]{2}{*}{ Count } & \multirow[t]{2}{*}{ Mean } & \multirow[t]{2}{*}{ Median } & \multicolumn{2}{|c|}{ Std. Dev. Minimum } & \multirow[t]{2}{*}{ Maximum } \\
\hline & & & & & & \\
\hline State shares & 1921 & 0.287 & 0.282 & 0.259 & 0.000 & 0.863 \\
\hline Legal person sharesı & 1921 & 0.189 & 0.075 & 0.226 & 0.000 & 0.903 \\
\hline Board size & 1921 & 9.397 & 9.000 & 2.142 & 5.000 & 19.000 \\
\hline Board independence. & 1921 & 0.801 & 1.000 & 0.399 & 0.000 & 1.000 \\
\hline CEO duality & 1921 & 0.131 & 0.000 & 0.338 & 0.000 & 1.000 \\
\hline Executive shares & 1921 & 0.009 & 0.000 & 0.051 & 0.000 & 0.638 \\
\hline Executive pay (CNY thousands) & 1921 & 819.972 & 568.000 & 880.812 & 14.000 & 10500.000 \\
\hline \multicolumn{7}{|l|}{ Bidder characteristics } \\
\hline Tobin's q & 1921 & 2.338 & 1.795 & 2.286 & 0.680 & 48.088 \\
\hline Leverage & 1921 & 0.143 & 0.114 & 0.123 & 0.000 & $0.788+$ \\
\hline Administration & 1921 & 0.735 & 1.000 & 0.442 & 0.000 & 1.000 \\
\hline Related transaction & 1921 & 0.605 & 1.000 & 0.489 & 0.000 & 1.000 \\
\hline Firm size (CNY millions) & 1921 & 7390.000 & 1850.000 & 40700.000 & 14.800 & 994000.000 \\
\hline \multicolumn{7}{|l|}{ Deal characteristics } \\
\hline Publictarget & 1921 & 0.062 & 0.000 & 0.242 & 0.000 & 1.000 \\
\hline Diversifying acquisition & 1921 & 0.902 & 1.000 & 0.298 & 0.000 & 1.000 \\
\hline All cash & 1921 & 0.901 & 1.000 & 0.299 & 0.000 & 1.000 \\
\hline All stock & 1921 & 0.044 & 0.000 & 0.205 & 0.000 & 1.000 \\
\hline Deal value (CNY millions) & 1921 & 276.000 & 38.900 & 1460.000 & 1.000 & 32800.000 \\
\hline Repeat bidder & 1921 & 0.730 & 1.000 & 0.444 & 0.000 & 1.000 \\
\hline
\end{tabular}

